\title{
Customer Relationship Marketing and The Challenge of System Trust in the Nigerian Retail Banking Context
}

\author{
Mujitaba Abubakar Tangaza \\ Lecturer, Department of Marketing, Umaru Ali Shinkafi Polytechnic \\ Sokoto,,matangaza@,gmail.com, www.orcid.org/0000-0002-2735-9633
}

\begin{abstract}
Alkasim Sidi Bello
Lecturer, Department Business Studies, Umaru Ali Shinkafi Polytechnic Sokoto, Alkasimsidi32@gmail.com,www.orcid.org/0000-0003-3548-1193
\end{abstract}

\begin{abstract}
Purpose - This study explores how system trust affects customer relationships management in the Nigerian retail-banking context, a country with weak institutions and infrastructure. Design/methodology/approach - this is an exploratory study based on qualitative research using semi-structured interviews with 27 managers, and a review of documents on the Nigerian retail banking system. Findings - The major findings of the study is that weak system trust - due to the weak legal framework, low literacy level and ineffective policing, has an influence on technologydominated relationship marketing and reinforces interpersonal trust in the Nigerian retail banking context. Practical implication- the findings are significant to research and practice concerning how system trust affects the relationship management strategy of retail banks in the Sub-Saharan African market, and how banks mitigate the effect of system trust through staffs' interpersonal trust-building effort. Originality/value - This study is among the very few studies that link CRM implementation and system trust in the retail banking context that operate in the Sub-Saharan African market.
\end{abstract}

Keywords: Customer relationship management, system trust, Sub-Saharan Africa market, Nigeria 


\section{Introduction}

This study aims to explore the impact of institutional/system trust - a trust that arises from the regulatory agencies and legal framework's ability to enforce rules and trust in the business context (Barbara, Ojijo, and Alemu, 2016). On customer relationship management in retail banking context of Sub-Saharan African (SSA) market. Beck, Chapman, and Palmatier, (2015) identified the need to understand the influence of system trust on selling organisations. In doing so, this research sought to explain and provide deeper insight into how the business context (external factors) of the organisation influence the trusting behaviour of customers. While some of these studies have examined how institutions and infrastructure within the business context influence brand trust, customer satisfaction and loyalty to the organisation (Beck, and Cull, 2013), others have examined how system trust influence banking relationship during a period of uncertainty (Breidbach, Kolb and Srinivasan, 2013), and the extent of such influence on banks and their representative (Carson, Gilmore, Perry, and Gronhaug, 2001). Creswell (2012), believe trust in a company and its representative is a necessary mediator of system trust. Although in another proposition. Creswell (2012) argue that both narrow trust - trust on the organisation and its representative that they can be trusted to deliver on their promises- and system trust is interwoven and one mediates the other, overall system trust moderates the effectiveness of narrow trust on the organisation. Crotty (2014) trust not only relates to customer trust in individual companies but also relates to the broader business context (system trust) in which consumers may plan and carry out their financial behaviour. In an environment with declining system trust during and after the 2008 financial crisis) customers may cease to trust the company and its representative (Dalziel, Harris, and Laing, 2011).

Still, other research extends this view and attempted to highlight how trust in the business context affect the marketing capabilities of a firm and their influence on the marketing approach of the organisation (EFInA. 2014). The underlying idea these studies tend to promote is that customer's trust in the business context, based on the perception that there is a strong regulatory oversight by government agencies and institutions to protect his investment, has a strong influence on narrow trust. EFInA. (2016) argued that institutions that regulate trustworthy behaviour and define acceptable and unacceptable acts affect trust in a firm and its representative.

While understanding the influence of system trust on narrow trust provides deep insight on customer relationship management in the banking context, with a few exceptions (Grayson, Johnson, and Chen, 2008). Consumer trust in the broader business context (i.e., system trust) has received very little attention (Hansen, 2012). However, all the above-mentioned research is Western-centric in origin and application (an environment with strong and relative development in infrastructure and institutions that generate trusting behaviour (Hansen, 2017).Specifically, they are focused mainly on how the financial crisis of 2008 generated weak system trust in the banking relationship. In particular, there is a paucity of research that examined this concept from SSA market perspectives. The fact that institutions and infrastructure that generate system trust in SSA are weak and provide weak confidence for people toward the business context that formal financial institutions operate. Hasan, Hasan, Lowe, Rahman, and Rahman, (2017) reflects the need for such research. Likewise, the fact that Nigeria, the context of the study, has high uncertainty avoidance that signifies low system trust. Lauckner, Paterson, and Krupa, (2012) signifies the gap of the study.

Sub-Saharan Africa, a marginalised continent with less economic attention from corporations and nations, is emerging and attracting the attention of large corporations and foreign direct investment (Mark, Philip and Adrian, 2016). This development is in tandem with the increased level of economic growth being registered by SSA countries (Marshall, and Rossman, 2011). For instance, Nigeria, the largest country in the region, recorded steady economic growth in recent 
times. Between 2009 and 2014, the Nigerian economy grew between 5\% and $6.2 \%$ per annum. Although Nigerian economic growth fell below 3.0\% in 2015 and 3.8 in 2016, as the Nigerian economy is expected to grow by $5.0 \%$ in 2017 . This projection is reinforced by Marshall, and Rossman, (2014) who argues that despite challenges, emerging Sub-Saharan African countries stand a better chance of economic recovery and growth than many developed countries.

Despite growing economic activity (The Economists, 2015), the Sub-Saharan African market is substantially different from the Western, high-income market because of weak external variables - infrastructural challenges, weak legal framework, low level of literacy and low level of technological capital (Mauro, Daniela, and Rodolfo, 2015). Marketing strategies of the firms that focus on the SSA market should therefore be made to suit the SSA own market and its surroundings because this market is also collectivist in nature. It is significantly different from Western-developed nations based on uncertainty avoidance. Informal cues that define acceptable and unacceptable behaviour reduce the level of uncertainty and complexities of economic life. These infrastructural/institutional challenges of SSA countries raise interesting points on how Sub-Saharan African external variables influence 'system trust', and trusting measures of customers towards banks in the SSA market. To address this gap in the literature, this paper aims to explore how weak institutions that generate system trust can affect customer relationship management in the retail-banking context of SSA, in the context of Nigeria. The study makes a significant contribution to the literature. First, based on empirical data, the paper extends marketing literature to cover the role of system trust in Nigeria, a non-Western context where no related research has been published (Merriam, 2014). Almost all institutions that generate system trust are weak in this context, and customers were reluctant about the ability of these institutions to protect their investment, which affects trust in the formal banks. However, staff Interpersonal trust-building effort reinforced by informal links that exist between customer and staff created a source of trust and confidence, and thus moderate the effect of system trust on banks. From a managerial perspective, an understanding of the impact of system trust, in this case, weak system trust is likely to provide banks with an opportunity to develop other measures (e.g., strong satisfaction measures) that will reduce the impact of weak system trust on the narrow trust. This is significant because most of the literature on system trust sought to examine system trust from a Western-based context. This paper seeks to understand the role of system trust in a context where high uncertainty avoidance exists, impersonal structures are weak and provide weak support for building narrow scope trust. Thus, institutions that generate system trust remain an important antecedent to effective CRM implementation in the SSA market. The remainder of this paper is organised into five sections. The second section discusses the research context; section three reviews the literature; Section four describes the data collection and analysis methods; section five reports the study findings and; section six discusses findings and conclusions from the study.

\section{Literature review}

As marketing scholars argued relationship marketing is not restricted to the exchange of service and money but rather how banks and customers can sustain ongoing and even trusting relationships over a long period of time. Trust is the central element in relationship marketing, and it is determined by not only narrow trust- trust on the bank, but also how business context is able to reduce business complexities and uncertainties in the economic life of a business. Consequently, effective management of the relationship is not restricted to internal processes that generate satisfaction, trust and loyalty alone. Scholars believe effective system trust in the business context influence effective management of the relationship between customer and the bank. Several theories have been advanced to describe the relationship between system trust and relationship marketing, and these theories focus on how customer trust in the broader business 
context that moderate market exchanges influence trust on firm and its representative. System trust literature found variables within the external environment to be the main drivers of system trust. Scholars that share this view believe the external environment -institutions, infrastructure that serves as guidance of trust - provides effective reasons for people to trust a firm and initiate a relationship with the organization $(\mathrm{PwC}, 2015)$. Institutions represent regulative agencies, legal framework and infrastructural development that create a climate of trust within the business context. Researchers describe the role of institutions in generating trusting behaviour from two perspectives. Some studies describe how a strong legal framework and regulative agency influence relationship marketing and create trusting relationships with the bank by inculcating a feeling of security, positive political atmosphere and certainty within the broader business context organisations operate. One of the issues considered is the strength of institutions in identifying untrustworthy behaviour and punishment; and how such an act influences customer decision to trust formal institutions and engage in a business relationship. In line with Burgess and Steenkamp. Wallace, (2014), argued that in an environment with weak institutions and lowlevel technological development relationship marketing implementation may yield a different result. They argue that trust in those institutions increases firm performance and a reduction in their operation and customer management cost. Thus, in an environment with weak institutions - legal framework, policing and low public trust, uncertainty exists and customers' belief informal institutions are reduced which eventually may affect the development of the effective customer-buyer relationship.

In addition, some of these studies on system trust specifically focus on the perception of security and confidence customers have in the regulative agencies during a time of uncertainty. Laukkanen, (2015) believe in the most developed nation due to strong institutions, the relevance of system trust is highly acknowledged in times of crisis only. System trust creates a climate of certainty in the business context during uncertainty, when a customer's narrow trust in a bank disappeared. Although the impact of system trust is contextual, Grayson et al. believe in a time of uncertainty, the customer may expect system trust to be more relevant in mediating buyerseller relationship. Customers rely more on regulatory bodies and institutions that identify untrustworthy to act and create confidence in the market. However, institutions and infrastructure that drive system trust are weak in Nigeria, and uncertainty avoidance that encourages acceptance of formal business is high in Nigeria, a typical sub-Saharan African country. Therefore, their impact in building confidence and system trust is perpetually weak. Consequently, system trust or the ability of regulatory bodies and intuitions that identify untrustworthy behaviour to act and create confidence is likely to be essential in sustaining narrow trust and profitable relationships between organisations and customers. Though this observation was suggested in prior research. Yin, (2010) research on system trust and banking relationships in a country with high uncertainty avoidance is very scant. Prior research in system trust literature explore this concept mostly after the 2008 financial crisis, their study is limited to Western-developed nations that have low uncertainty avoidance, strong institutions and infrastructure that support broad context trust (system trust) generation.

Likewise, also generally cited is the role of institutional frame in creating confidence within the business context and hence narrow trust in the banking relationship. In line with institutional theory, Inoue and Hamori. Kendall, Clark, Rhymer, Kuznesof, Hajslova, Tomaniova, and Frewer, (2019) describe the level of education as an important cue in promoting system trust in an environment dominated by uncertainty and weak regulative agency. In the SSA context, it is expected that those with low literacy levels are more likely to have a negative perception of formal banking and its product. Consequently, they tend to avoid and sometimes engage banks through interpersonal means level of education support customer cognitive effort, easy 
acquisition of financial knowledge and acceptance of formal banking product. Customers with Western-based education can comprehend banking product attributes easily and behave in a financially responsible manner. As discussed previously, literacy reduces such negative perceptions on banks that dominate the SSA context and encourages trust in the business and banking relationship. To improve banking relationships, acknowledge the need for reducing the barriers to low education in Sub-Saharan Africa. Consequently, a low literacy level is likely to mediate system trust and banking relationships. However, its impact on system trust and relationship marketing in the retail banking context that operates in the SSA market remain sparse. The level of literacy is high in Western developed nations, and its ability to influence cognitive knowledge on financial literacy and hence its influence on system trust has been explored in context with a high level of literacy. One challenge is a low level of literacy may likely influence system trust and banking relationships in Nigeria, given the existence of high uncertainty avoidance and low infrastructure that promote system trust and banking relationships in the SSA context (Lee, Kim, Lee, and Shin, 2015).

In addition, there is a large distance between Western-developed countries, where all the studies on system trust and banking relationship were conducted, and the SSA market. Economically, culturally and technologically, they are different, and these differences could affect the ability of institutions that generate system trust to protect and safeguard customer investment. Given the importance of infrastructure and institutions in the generating system and the role of system trust in mediating narrow trust on bank and relationship marketing, it is surprising that there is very little work that explores how system trust affects banking relationships in Nigeria, a typical SSA market. In the present research, the role of system trust has been explored in an effort to understand its relationship with customer relationship marketing. To explore this concept, the study is guided by the research questions below:

- How do institutions that generate trust affect relationship management implementation in the Nigerian retail banking context

- How do interpersonal trust-building activities of staff influence and negate the impact of weak system trust in a banking relationship?

\section{Methodology}

The methodology of this paper is based on qualitative research that seeks to explore the role of system trust on banking relationships in Sub-Saharan Africa. This approach was selected based on a reported paucity of relationship marketing research that focuses on the SSA market. This approach allows authors to undertake in-depth study and uncover how the business context in which banks operate affect the banking effort of relationship marketing by affecting trust formation antecedents. Similarly, it's the viable methods that enable researchers to uncover context-dependent knowledge because the context and the phenomena are interwoven (Nwankpa, and Datta, 2021), and context influences different meanings and perceptions that participants ascribed to trust formation and relationship management. Thus, one of the researchers personally participated in data collection by visiting the setting of the study and interacting with managers in a face-to-face manner. The researcher who acted as a research instrument is fluent in the local language and English and share a similar culture with most of the participants.

Three major banks were selected based on their concerted effort to strengthen their relationship with retail customers because of Government policy that has led to a reduction of public sector investment that many banks rely on. In 2013, CBN introduces a Cash reserve ratio of 75 on public 
sector investment. In 2015, another government policy was introduced that moved all public sector account to CBN. For this study three best performing banks with wide coverage, based on The Banker Magazine review of the top twenty banks in Africa in 2013, were selected. Similarly, these banks made a huge investment in building a relationship with customers. The research participants were purposefully drawn from these banks because they are expected to have firsthand experience and understanding of the research problem and phenomena in the study. In each of these banks, potential research respondents with knowledge of the research area were identified (Odusanya, Aluko, and Lal, 2020).

Primary data collection involved the use of semi-structured, face to face interviews with twentyseven managers (Table 1). The use of semi-structured interviews is to uncover new issues not discovered before. Therefore, the most important thing, in this case, is the selection of managers who are skilful and are willing to offer insight on the issue or subject of discussion. Specifically, mindful of explanation, the interviews assumed informal discussion patterns and used simple language to enable respondents to respond to questions being asked in their words. The discussion with the managers was moderated by the principles of saturation when additional interviews failed to generate additional insight.

Managers view was further triangulated with qualitative data; banks reports, KPMG annual report on banking in sub-Saharan Africa (KPMG, 2014), Nigerian banking industry customer satisfaction survey (KPMG, 2014), financial inclusion studies in the Nigerian context (EFInA, 2014, 2016), and literature on banking sector reforms in Sub-Saharan Africa formed the main sources of secondary data. Further validity measures were enhanced by interviewing a different set of managers, both senior and middle managers in these three banks. In consonance with, managers were chosen based on acquaintance and convenience with the interviewer.

After the collected interview data were transcribed, the dissembling and reassembling method outlined by (Ciampolini, Tozetto, Milan, Camiré, and Milistetd, 2020) was used to analyse the data. At disassembling stage, data is broken down into codes. While at reassembling stage, codes were grouped into subcategories and categories to identify key themes. As potential categories and themes emerged from the early stage of data analyses, a back and forth procedure: within and between categories to confirm and validate emerged themes was conducted. As final themes emerged, further clarification and understanding of collected data were strengthened by revisiting various literature on customer relationships. Emerged themes were presented and discussed as research findings. Pseudonyms are assigned to describe participating managers as a condition for anonymity.

Table 1 Participants Description

\begin{tabular}{|l|l|}
\hline Code & Respondents \\
\hline R1 & General Manager \\
\hline R2 & Deputy General Manager \\
\hline R3 & Deputy General Manager \\
\hline R4 & Deputy General Manager \\
\hline R5 & Assistant General Manager \\
\hline R6 & Assistant General Manager \\
\hline
\end{tabular}


Journal of Management and Economic Studies, vol.3, issue.3, pp.102-114

\begin{tabular}{|c|c|}
\hline R7 & Assistant General Manager \\
\hline R8 & Assistant General Manager \\
\hline R9 & Senior Manager \\
\hline R10 & Senior Manager \\
\hline R11 & Senior Manager \\
\hline R12 & Senior Manager \\
\hline R13 & Senior Manager \\
\hline R14 & Senior Manager \\
\hline $\mathrm{R} 15$ & Relationship Managers \\
\hline R16 & Relationship Managers \\
\hline R17 & Relationship Managers \\
\hline $\mathrm{R} 18$ & Relationship Managers \\
\hline R19 & Account Managers \\
\hline $\mathrm{R} 20$ & Account Managers \\
\hline $\mathrm{R} 21$ & Account Managers \\
\hline $\mathrm{R} 22$ & Account Managers \\
\hline $\mathrm{R} 23$ & Middle Level Manager \\
\hline $\mathrm{R} 24$ & Middle Level Manager \\
\hline $\mathrm{R} 25$ & Middle Level Manager \\
\hline $\mathrm{R} 26$ & Middle Level Manager \\
\hline $\mathrm{R} 27$ & Middle Level Manager \\
\hline
\end{tabular}

\section{Designed by Author}

\section{Findings}

\section{Weak technological capital and legal framework}

A question "how does the external environment affect bank effort in relationship management guided data collection. The findings supported the view that technology penetration is an important prerequisite for effective relationship management in the retail banking sector. The feeling is that when a customer can access technology-enabled channels, access to bank products 
is made easy; and banks' ability to relate with customers and offer differentiated service can be facilitated with ease, as customers can engage with the bank in several ways and enable the bank to collect and store customer data for future reference and strategic customer decision formulation and implementation. This can further facilitate the excellent customer-bank relationship and strengthen narrow trust in banks and its representative. Managers felt that an environment that supports multiple channels' use in smooth service delivery is essential, and this is not within the powers of the banks to improve.

"Poor technology penetration is also a challenge. Of cause the number of internet users is growing we are still not there yet. So, that is also another challenge, especially in our mass retail segment. You find out that if you have the basic phone that may not be able to deploy some of the applications that we send out to our customers (R11)".

Analysis has further revealed that anxiety and lack of confidence that originate from the weak trust people have in institutions that support trust in the business context weaken customer ability to into banking relationships. The insecurity of such channels discourages satisfaction and increases costs that banks incur when customers, persistently, use the branch and other interpersonal channels to conduct banking transactions. What is more concerning is the fact that there is a negative perception towards technology-enabled channels given the weak trust in the government ability to protect citizens' investment, and the environment is beyond bank control. Its impact affects customer satisfaction measures of the bank, and the banks' ability to develop and build an excellent brand relationship with the few customers that can afford banking products. This perception increases apprehension of interpersonal channels, as the general public displays low satisfaction and a low level of apprehension in the use of several banking products (e.g., credit card, Internet banking, and call centre) (EFInA, 2014, 2016; KPMG, 2014, 2016) that are vital for brand relationship in the retail banking context. As emphasised by managers, institutions of trust-building, such as police, legal framework and political environment inhibit system trust formation and create an environment of fear and lack of trust in other non-personal means of customer interaction.

"We have a justice system that is not effective and efficient. There are instances where banks need protection from a customer or need redress for the customer. For instance, customers who attempt to make fraud in the system even affect some of your customers. The judicial system does not confer banks in Nigeria the advantage of easily bringing those kinds of characters to justice...There are a lot of tedious processes. You approach a court of law, the case will be adjourned, and the judgement will be delayed for a month if not years and others. So this kind of delay affects customer patronage and respond to customer complaints (R8)".

In consonance with the above-mentioned view, lack of system trust creates a lack of structural assurance and lack of situational normalcy of customer-facing channels, which affect customerbank interaction and put more pressure on the bank's single most patronised channel of communication, that is, the branch. This in turn affects integrity and benevolence created by the organisational processes via customer-facing channels that are technologically enabled and hence the banking relationship, subsequently, increase the cost of interpersonal relationships between customers and banking staff.

“They are always in our branch. Yes! Customers. We don't want it because it costs us money to maintain a branch. But they are not using other channels. We always encourage them to use our call centre for whatever complain they have (R6)".

Linked with this view and inconsonant with EFInA a review of financial inclusion status, "Technology-enabled channels, ATM card, point of sales terminals are not totally trusted In Nigeria given the internet challenges". The significant influence of system trust as an important 
antecedent to a brand trust formed a challenge to effective CRM implementation in this context. This further reflects the significant role of the external environment in banking relationships.

\section{Low Literacy level}

The acceptance of formal banking service and the willingness of a customer to retain constant business interaction with the bank in an environment with a low level of literacy formed a voice of concern among several managers interviewed. Insight from the interview reveals open viewpoints concerning its impact on a bank's CRM strategy because it delays service delivery and trust in the formal financial institutions. Some customers, especially in mass, tier one and tier two, find it difficult to read or write since they lack formal education, which affects their cognitive ability to analyse financial offers, and thus banks require boundary spanning capability to manage the customer relationship. Employment of staff that are conversant with local language and reflect the acceptable norm and culture in the bank's location prove important in communicating to customers.

"Literacy in terms of the level of education is a major challenge. Because most of our product offerings require that you have that basic literacy level to be able to read and write, to be able to sign to read an account opening package, understand your obligation and what is expected of you from the bank. So that is a challenge to customer engagement effectively. For some customers, you have to interpret every bit of what you do to them. Every corresponds you have to sit down and interpret to them (R10)".

Customers' inability to communicate in formal language limited their trust in the bank, and link their allegiance to staff that understands local language and has some link with them religiously or based on some cultural link. By implication, the low literacy level renders the trust they have informal institutions weak. They have a negative perception of Western education. Couple with the weak institution of the legal framework and policing, customer ability to a bank is weak, it increases their lack of apprehension on technology-enabled contact channels and distances them from using them. This aligns with Zins and Weill argument that as Western education increases among people in Sub-Saharan African, their level of financial education and confidence/ trust in government increases. Conclusively, views from managers further suggest that low public satisfaction with the performance of the institution in generating trust affects how customers perceive and use technology-enabled channels, thereby reducing the impact of bank information systems on customer data generation, and hence relationship management. At the same time, they inhibit relationship quality by compromising truth and commitment that form major factors in the banking relationship.

\section{Interpersonal trust}

The interview data revealed yet another finding that system trust does not affect the general acceptance of the formal banking system but rather weaken the brand relationship that the technology-dominated relationship marketing strategy intends to achieve. It promotes interpersonal trust effort and depicts bank CRM strategy as a relationship marketing strategy that focuses on customer-front line staff relationships. As customers felt unsure about the use of technology-enabled channels that tend to isolate contact with staff, customers tend to favour direct relationships with staff. Given the overwhelming presence of banking staff that are conversant with the local language, and customers that are sensitive to ethnic and religious links, there is genuine trust to staff than the bank as a brand.

"If you are my brother (share of religious and ethnic affiliation) you will feel more relaxed and comfortable than when someone who is not your brother is managing your relationship. As a 
customer, you have more trust in someone who is linked to you culturally than someone who is $\operatorname{not}(\mathrm{R} 14)^{\prime \prime}$.

This perception reflects that many customers have a strong belief in the trust they build with people rather than with financial institutions. The effort of marketing staff and their link with the environment where banks operate suppress weak system trust impact. People need to see people they know promoting financial service, and in return boundary spanning capability remain a source of competitive advantage to the bank. Specifically, banks focus on fronting people that originate from the surroundings as a way of marketing banks and their product because customers link the presence of staff they see a part of them in the bank with a measure of trust, and their lack of confidence in the institution that generates trusting believe is reduced. So what interpersonal trust measure did is to induce and strengthen banking acceptance through a representative of the bank. "There is nothing as important as a person to person interaction in offering bank competitive advantage (R13)".

These views were triangulated by several responses that show how bank staff engages in acts of personal trust-building (e.g., frequent customer visitation) to negate weak system trust and encourage banking acceptance. As part of banks effort to encourage acceptance to negate weak system trust, interpersonal trusting efforts extend to phone calls, visiting small businesses that were owner-managed businesses in nature and engaging with customers personally to build a relationship. Indeed, due to the low confidence people have in the formal banking system, banks developed a marketing strategy that focuses on trust-building efforts to strengthen trust, confidence and customer loyalty. Findings revealed that all commercial banks in the industry engage and promote laundry spanners' capability in interpersonal trust-building and see it as a strategic effort that reduces the challenge of system trust and banking patronage by customers.

\section{Discussion}

This qualitative research based on semi-structured interviews explored how weak system trust affects the customer relationship management strategy of the banks in the SSA market. Within the SSA market context, the study explored how the Nigerian external environment affects a generation of institutional trust that significantly mediate the effectiveness of narrow trust on banking relationship. The finding has so far revealed that although customers patronised retail banks, low technological capital, weal legal framework and low literacy level weaken customers' system trust, and his ability to engage into a brand relationship that relationship management effort of the bank intends to achieve.

In consonance with the finding reflected a typical weakness of antecedent to narrow trust - a trust that boosts brand and banking relationship. At the same time, it reflects how the lack of structural assurance and lack of situational normalcy - an environment that creates security while in banking relationship, generated through the effectiveness of legal framework and institutions that strengthen system trust and customer confidence in formal financial institutions, create weak system trust, and hence promote trust at the personal level. This finding was supported by the inability of institutions to create confidence in technology-enabled channels that link customers with a bank and create a brand relationship, importantly in the retail banking context because, in this context, banks deliver essential banking services to customers via such channels. The inability of such institutions to offer confidence in the business context generates a negative perception towards technology-enabled channels and the bank. Thus, as noted by highlighting the weak system based trust, it can be concluded that institutions that create system trust have a significant influence on the relationship management strategy of the bank in the SSA market. This contribution is significant since very few studies identify the link between CRM implementation and system trust in the retail banking context that operates in a SSA market. 
Finally, the study findings as reported here believe in an environment with a high level of literacy people have weak trust in the formal system and their anxiety about the bank is high. However, an interpersonal trust-building mechanism based on boundary spanning capability, due to cultural linkages that create trusting measures among people, can reduce the level of anxiety and make people bank. This development reflects the important role of lower-level managers and frontline staff in the relationship management effort of banks that operate the SSA market. Senior managers need to provide training and time for lower-level managers, and the CRM strategy of the banks should adopt a bottom-top approach where input from the low-level managers remain of primary importance.

\section{Managerial implication}

As the aim of the study indicated, it explores the significance of system trust on customer relationships management in the context of retail banks. Insight from the interviews explains how institutions that generate trusting measures in the business context affect narrow trust on banks and relationship management. Weak institutions that are prevalent in the SSA market reduce system trust and create anxiety and weaken customer trust informal banking and banking relationships. In this case banks in Nigeria deploy interpersonal trust-building efforts to illuminate boost trust, since customers are receptive to cultural links, and they see them as an important trusting measure in building a relationship. The major implication and more concerning is that this finding is based on retail banking context that is supposed to focus on creating a brand relationship and direct trust to the bank; because most investment in customer relationship management is aimed at reducing the cost of interpersonal trust and building trust on the bank. This suggests that as adoption of interpersonal trust mechanism in banking relationships is reasonably low in a retail context in comparison with key account management (KAM) context, the challenge may even greater in the KAM context. This signifies opportunities for future research.

\begin{tabular}{|l|l|l|l|}
\hline \multicolumn{3}{|c|}{ Table 2 Summarised Analyses based on supported Code } \\
\hline S/N & $\begin{array}{l}\text { Observed } \\
\text { areas }\end{array}$ & Supported codes & Position taken \\
\hline 1. & $\begin{array}{l}\text { Weak } \\
\text { technological } \\
\text { capital and legal } \\
\text { framework }\end{array}$ & R6, R11, R8 & $\begin{array}{l}\text { Thus low technology acceptance affect broad } \\
\text { context trust on retail bank and hence relationship } \\
\text { management strategies of the bank. However, due } \\
\text { to weak broad context trust on retail banks } \\
\text { interpersonal relationship continue to dominate } \\
\text { banking relationship in SSA context, which shows } \\
\text { that the effectives of strategies design to build } \\
\text { brand trust, is determined by strong technological } \\
\text { acceptance and high literacy level }\end{array}$ \\
\hline 2. & Low Literacy level & R10 & $\begin{array}{l}\text { The low literacy level renders the trust they have } \\
\text { informal institutions weak }\end{array}$ \\
\hline 3. & Interpersonal trust & R13, R14, & $\begin{array}{l}\text { This perception reflects that many customers have } \\
\text { a strong belief in the trust they build with people } \\
\text { rather than with financial institutions. }\end{array}$ \\
\hline
\end{tabular}




\section{References}

Barbara, B., Ojijo, O., \& Alemu, Z. (2016). African Economic outlook 2016. Abidjan: African Development Bank African development Bank

Beck, J. T., Chapman, K., \& Palmatier, R. W. (2015). Understanding relationship marketing and loyalty program effectiveness in global markets. Journal of International Marketing, 23(3), 121.

Beck, T., \& Cull, R. (2013). Banking in Africa. World Bank Policy Research Working Paper(6684).

Breidbach, C. F., Kolb, D. G., \& Srinivasan, A. (2013). Connectivity in Service Systems Does Technology-Enablement Impact the Ability of a Service System to Co-Create Value? Journal of Service Research, 16(3), 428-441.

Carson, D., Gilmore, A., Perry, C., \& Gronhaug, K. (2001). Qualitative marketing research: Sage.

Creswell, J. W. (2012). Qualitative inquiry and research design: Choosing among five approaches: Sage.

Creswell, J. W. (2014). Research design : qualitative, quantitative, and mixed methods approaches (Fourth edition, international student edition. ed.). Califonia: SAGE Publications.

Crotty, J. (2014). Corporate Social Responsibility in the Russian Federation A Contextualized Approach. Business \& Society, 55(6), 825-853.

Dalziel, N., Harris, F., \& Laing, A. (2011). A multidimensional typology of customer relationships: from faltering to affective. International Journal of Bank Marketing, 29(5), 398-432.

EFInA. (2014). EFInA Access to Financial Services in Nigeria 2014 Survey (Report). Retrieved 17/09/2015 http://www.efina.org.ng/our-work/research/access-to-financial-services-innigeria-survey/efina-access-to-financial-services-in-nigeria-2014-survey/

EFInA. (2016). Access to Financial Services in Nigeria 2016 Survey. Retrieved from Nigeria: http://www.efina.org.ng/assets/ResearchDocuments/a2f2016/Updated/Focus-GroupDiscussions-2016-Key-Findings.pdf

Grayson, K., Johnson, D., \& Chen, D. F. R. (2008). Is firm trust essential in a trusted environment? How trust in the business context influences customers. Journal of Marketing Research, 45(2), 241-256.

Hansen, T. (2012). The Moderating Influence of Broad-Scope Trust on Customer-Seller Relationships. Psychology \& Marketing, 29(5), 350-364.

Hansen, T. (2017). The moderating effects of financial broad-scope trust on consumer knowledge, cognitive effort, and financial healthiness. Journal of Consumer Behaviour, 16(2), 161-175.

Hasan, M. R., Hasan, M. R., Lowe, B., Lowe, B., Rahman, M., \& Rahman, M. (2017). Visual cues and innovation adoption among bottom of the pyramid consumers. Qualitative Market Research: An International Journal, 20(2), 147-157.

Lauckner, H., Paterson, M., \& Krupa, T. (2012). Using constructivist case study methodology to understand community development processes: Proposed methodological questions to guide the research process. The Qualitative Report, 17(13), 1-22.

Mark, S., Philip, L., \& Adrian, t. (2016). Research Methods for business students. Essex England: Pearson Education Limited.

Marshall, C., \& Rossman, G. B. (2011). Designing qualitative research (5th ed. ed.). London: SAGE. 
Marshall, C., \& Rossman, G. B. (2014). Designing qualitative research: Sage publications.

Mauro, M., Daniela, M., \& Rodolfo, M. (2015). Recent Trends in Banking in sub-Saharan Africa From Financing to Investment. Retrieved from http://www.eib.org/attachments/efs/economic_report_banking_africa_from_financing_to _investment_en.pdf

Merriam, S. B. (2014). Qualitative research: A guide to design and implementation: John Wiley \& Sons.

PwC. (2015). What next for Nigeria's economy? Navigating the rocky road ahead PwC's economic scenarios for 2015 and 2016. Retrieved from http://www.pwc.com/ng/en/pressroom/economic-scenarios-for-nigeria-2015-and-2016.html

Wallace, P. (2014). Top 1000 World Banks - Africa's biggest banks endure a tough year. Retrieved from http://www.thebanker.com/World/Africa/Nigeria/Top-1000-World-Banks-Africa-sbiggest-banks-endure-a-tough-year

Yin, R. K. (2010). Qualitative research from start to finish: Guilford Press.

Laukkanen, T. (2015, January). How uncertainty avoidance affects innovation resistance in mobile banking: The moderating role of age and gender. In 2015 48th Hawaii International Conference on System Sciences (pp. 3601- 3610). IEEE.

Kendall, H., Clark, B., Rhymer, C., Kuznesof, S., Hajslova, J., Tomaniova, M., ... \& \& Frewer, L. (2019). A systematic review of consumer perceptions of food fraud and authenticity: A European perspective. Trends in Food Science \& Technology, 94, 79-90.

Lee, J. G., Kim, K. J., Lee, S., \& Shin, D. H. (2015). Can autonomous vehicles be safe and trustworthy? Effects of appearance and autonomy of unmanned driving systems. International Journal of Human-Computer Interaction, $\quad 31(10), 682-691$.

Nwankpa, J. K., \& Datta, P. (2021). Leapfrogging Healthcare Service Quality in Sub-Saharan Africa: The Utility-Trust Rationale of Mobile Payment Platforms. European Journal of Information Systems, 1-18.

Odusanya, K., Aluko, O., \& Lal, B. (2020). Building consumers' trust in electronic retail platforms in the sub-Saharan context: an exploratory study on drivers and impact on continuance intention. Information Systems $\quad$ Frontiers, 1-15.

Pearce, A., Harrison, M., Watson, V., Street, D. J., Howard, K., Bansback, N., \& Bryan, S. (2021). Respondent understanding in discrete choice experiments: a scoping review. The Patient-Patient-Centered Outcomes Research, 14(1), 17-53.

Ciampolini, V., Tozetto, A. V., Milan, F. J., Camiré, M., \& Milistetd, M. (2020). L Lifelong learning pathway of a coach developer operating in a national sport federation. International Journal of Sports Science \& Coaching, 15(3), 428-438. 